\title{
Phage-Display-Derived Peptide Specific to Carbamylated Protein
}

\author{
Yuhao Ma, Meng Wu, Shuhui Li, Marcello Tonelli, and Larry D. Unsworth*
}

Cite This: ACS Omega 2021, 6, 3079-3089

Read Online

ABSTRACT: Protein carbamylation has been linked with diseases commonly associated with patients with reduced kidney function. Carbamylated human serum albumin (cHSA), which has been proven to be nephrotoxic and associated with heart failure for chronic kidney disease (CKD) patients, was chosen for our study. Through phage display against cHSA, one specific peptide sequence ( $\mathrm{cH} 2$-p1) was identified with higher selectivity toward cHSA over native HSA. The $\mathrm{cH} 2$-p1 peptide was synthesized, and its target binding was analyzed through isothermal titration calorimetry (ITC). The result showed that $\mathrm{cH} 2-\mathrm{p} 1$ was able to bind cHSA of different levels of carbamylation with a similar dissociation constant of $\sim 1.0 \times 10^{-4} \mathrm{M}$. This peptide also showed

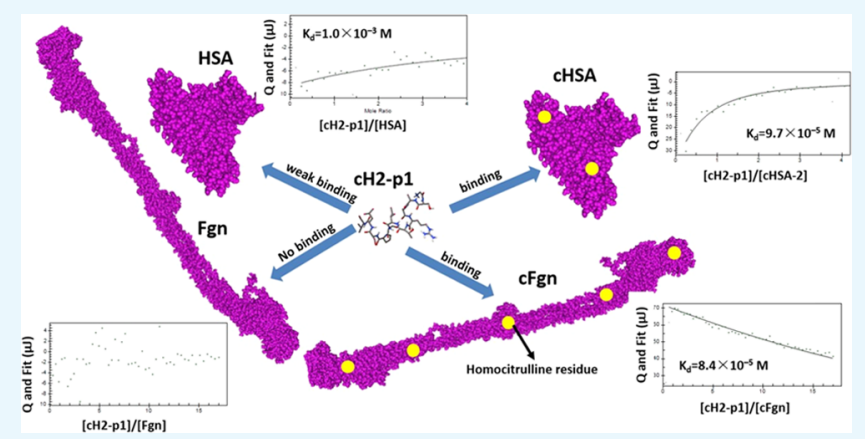
a binding specificity to carbamylated fibrinogen (cFgn), while not binding to native Fgn at all. For better understanding of the binding mechanism of $\mathrm{cH} 2$-p1, competitive binding of $\mathrm{cH} 2$-p1 and anti-homocitrulline to cHSA was performed, and the result revealed that $\mathrm{cH} 2$-p1 may bind to homocitrulline residues in a similar manner to the antibody. A molecular docking study was further performed to investigate the favored binding conformation of homocitrulline residue to cH2-p1. This work demonstrates the potential of peptides as a specific binding element to carbamylated proteins.

\section{INTRODUCTION}

Carbamylation is a protein post-translational modification that usually arises during the progression of chronic kidney disease (CKD). The buildup of urea in the blood of CKD patients leads to an increase in its decomposition product, isocyanic acid, which reacts with the lysine $\varepsilon$-amino group and turns lysine residues into homocitrulline during the process of carbamylation. As a result, the nature ${ }^{1-4}$ and function ${ }^{5-9}$ of proteins are significantly altered and have been associated with numerous health concerns such as atherosclerosis, ${ }^{10}$ cataracts, ${ }^{11}$ arthritis, ${ }^{12}$ and Alzheimer's disease. ${ }^{13}$ Carbamylation of human serum albumin (HSA) has been reported to show enhanced nephrotoxicity with an increased possibility of tubular cell damage and peritubular fibrosis. ${ }^{14}$ In addition, it was found that carbamylated albumin was strongly associated with cardiovascular mortality and sudden cardiac death; the role of carbamylation in the pathophysiology process has been suggested. ${ }^{15}$ Clearance of carbamylated proteins has long been a problem using membrane-based dialysis treatments as they cannot be differentiated from normal proteins based solely upon size differences. Accumulation of carbamylated (cHSA) in uremic patients undergoing hemodialysis seems to be inevitable. ${ }^{16}$ A specific strategy has to be developed to enable selective removal of carbamylated proteins, viz., albumin, so as to enhance patient outcomes.

Previous work has shown that it is possible to target homocitrulline-containing proteins. Specifically, the presence of an anti-homocitrulline-containing protein antibody has been found in the autoantibody system for rheumatoid arthritis (RA) patients. ${ }^{17}$ Also, inoculating animals with peptides or proteins containing homocitrulline produces antibodies against these carbamylated proteins. For instance, polyclonal antibodies against carbamylated low-density lipoprotein (cLDL) were produced by immunizing guinea pig $^{18}$ and rabbits ${ }^{19}$ with cLDL. The anti-cLDL antibody produced from rabbit showed low cross-reactivity toward native LDL or other LDL isoforms. Likewise, in another study rabbits immunized with carbamylated HSA produced serum that has equally strong, off-target, binding to homocitrulline-containing collagen telopeptides as serum generated from carbamylated type I collagen immunization. ${ }^{20}$ From western blotting of anti-carbamylated protein antibodies for fetal calf serum with carbamylation, carbamylated albumin was found with the most intense band. ${ }^{21}$ All of these findings indicate that antibodies that target carbamylated proteins are in fact specific toward the homocitrullinecontaining species, regardless of the protein it is found in. That said, it has been found that antibodies formed against homocitrulline do have some cross-reactivity against citrulline moieties which are formed through a whole different

Received: November 9, 2020

Accepted: January 13, 2021

Published: January 25, 2021 
mechanism than homocitrulline. ${ }^{22}$ For the application of removing carbamylated proteins from uremic patients, this citrulline cross-reactivity would actually allow for their removal from the blood compartment as well perhaps mitigating unwanted effects.

Despite the fact that antibodies against carbamylated albumin have been identified from anti-sera, ${ }^{20,23}$ there are several issues with their widespread application. Namely, none of the amino acid sequences for antibodies against homocitrulline-containing proteins has been reported, to the best of our knowledge. The large scale production of antibodies is a significant barrier to their application, having low yields, with limited repeatability. ${ }^{24}$ In comparison, phage display techniques allow for antibody-like peptide generation with an easier procedure and a larger scale of production. ${ }^{25}$ To date, there has been no phage display-derived peptide identified for carbamylated protein, despite their recognized potential in selective protein removal. ${ }^{26}$ In this study, we have identified such peptide ligands that are possible for isolation of carbamylated HSA without binding native HSA.

\section{RESULTS AND DISCUSSION}

2.1. In Vitro Carbamylation. To mimic the physiological condition, the extent of carbamylation should be similar to that contained in uremic patients. However, the problem is that in uremic patients the carbamylated and uncarbamylated albumins are always present; making it hard to distinguish the precise extent of carbamylation present for albumin. One study has determined that the proportion of highly carbamylated HSA, at Lys-549, within the blood varied from 0.1 to $3 \%{ }^{27}$ This implies that only a small fraction of HSA was carbamylated to any extent, even if multiple lysine residues were affected. Mapping of carbamylation sites through fragmentation and multiple reaction monitoring (MRM) studies identified up to two lysine sites (Lys-549 and Lys160) of the 59 present in HSA to be significantly more susceptible to carbamylation. Hence, we may roughly estimate the real carbamylation extent, or Hcit\%, from $1.7 \%(1 / 59)$ to $3.4 \%(2 / 59)$.

In vitro carbamylated HSA was prepared as a model carbamylation target. Homocitrulline level was used as a measure for the degree of carbamylation and was varied from $0.54 \%$ (cHSA-1) to $3.7 \%$ (cHSA-3) (Table 1 ). The purity of

Table 1. cHSA and cFgn Prepared through In Vitro Carbamylation

$\begin{array}{llc}\text { sample } & \text { Hcit\% }(\%) & \zeta \text {-potential }(\mathrm{mV}) \\ \text { HSA } & 0 & -7.46 \pm 0.65 \\ \text { cHSA-1 } & 0.54 \pm 0.22 & -7.84 \pm 0.59 \\ \text { cHSA-2 } & 2.7 \pm 0.18 & -10.8 \pm 0.44 \\ \text { cHSA-3 } & 3.7 \pm 0.17 & -11.7 \pm 0.75 \\ \text { Fgn } & 0 & \\ \text { cFgn } & 12.0 \pm 1.2 & \end{array}$

cHSA and cFgn was verified through ABA assay, and the 0 absorbance at $310 \mathrm{~nm}$ proved the absence of residual cyanate. To verify the in vitro stability over carbamylation, an sodium dodecyl sulfate-polyacrylamide gel electrophoresis (SDSPAGE) study was performed. For both cHSA and cFgn used in this study, their bands remained unchanged compared to their native protein (see Supporting Information Figure S1). This is not surprising as cyanate only binds to a small fraction of lysine side chains, producing a negligible change in molecular weight, nor will it cleave the peptide bond. It has been reported that the Stoke's radius for BSA increased slightly upon carbamylating. ${ }^{3}$ Here, in our study, it was confirmed by dynamic light scattering, where a hydrodynamic diameter of native HSA increased from 9.4 to $12.6 \mathrm{~nm}$ for cHSA-1, and remained without further change for cHSA-2 (see Supporting Information Figure S2). This might indicate that the protein size is only sensitive to change at a very slight degree of carbamylation.

2.2. Identification of Candidate Phage Clones that Bind to cHSA. The Ph.D.-12 library was used to select peptides that specifically bind cHSA. The 12 mer random library gives a complexity of $10^{9}$ variant clones and allows for more complicated folding structure than 7 mer library. We found no antibody sequence recorded in IMGT databases for homocitrulline-containing species. ${ }^{28,29}$ However, there were 31 sequences listed, with the acc. number from AJ430734 to AJ430772, for antibodies against citrulline-containing peptide. ${ }^{30}$ It is worth noting that one commercial antibody, considered citrulline-specific, has been found to be able to recognize both homocitrulline- and citrulline-containing albumins. ${ }^{20,31}$ Moreover, given that each of three complementarity-determining regions (CDR) are 7-15 amino acids, a 12 mer peptide is a reasonable choice to develop analogues to these CDRs.

The importance of negative biopanning to remove peptides from the library that have any affinity toward native HSA cannot be overstated as it has already been shown that disulfide-constrained cyclic peptide phage display libraries derived from M13mp18 have been used to develop peptides that specifically bind HSA. ${ }^{32}$ Therefore, we reduced the phage library used for cHSA targeting through exposing the native library to HSA coated 96-well plate surfaces (twice repeated). Biopanning against cHSA-1 yielded only one sequence (APPHVSSTVSWL) in all picked plagues after only one round. This sequence did not match any TUP record stored in the SAROTUP database; however, it could be that this sequence has a high propagation bias due to its similarity to APWHLSSQYSRT, which is a notoriously high propagation rate peptide. ${ }^{33-35}$ PHD7FASTER prediction revealed that it has a 0.96 probability to have a propagation advantage. Enzyme-linked immunosorbent assay (ELISA) results for these phage isolates ( $\mathrm{cH} 1-\mathrm{p} 1)$ failed to exhibit significantly higher absorbance on cHSA-1 compared to HSA (Figure 1). Thus, we speculate that cHSA-1 may have lacked sufficient chemical features distinct from HSA and therefore no other peptides bound cHSA-1 after negative screening.

To increase the specificity for targeting carbamylated HSA, a higher Hcit\% HSA was used for phage display (cHSA-2). After four rounds of biopanning, a number of sequences with high variability were obtained (see Supporting Information Figure S3). Although it is expected that with repeated biopanning and amplification, clone variation should be reduced and a consensus sequence be resolved, this was not the case; after four rounds, new sequences were still observed. Sequence alignment did not yield any highly conserved motifs (see Supporting Information Section S3). Incorporating additional rounds of biopanning may not have helped in reducing the number of binding phages, as it may cause a selection bias toward phage that has a growing advantage. Nevertheless, there were several clones that appeared more frequently than others, and the top 6 clones were picked together with $\mathrm{cH} 1-\mathrm{p} 1$ (Table 


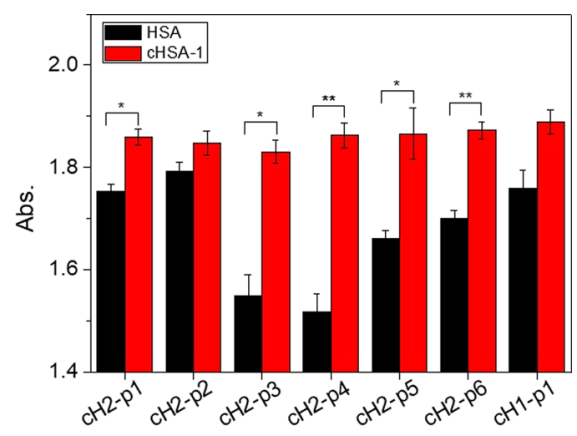

Figure 1. Affinity of candidate phages obtained through the phage display biopanning targeting cHSA to native HSA and carbamylated HSA (cHSA-1) (data represent mean \pm 1 standard deviation (SD), $n$ $=3 ; *, p<0.01 ; * *, p<0.001)$.

2). The amino acid population was ranked according to their occurrence frequency for all clone sequences for cHSA-2 binding peptides (see Supporting Information Table S1). We found serine, alanine, proline, leucine, and threonine are the most abundant amino acids observed in these systems, and they are all constitutes in both $\mathrm{cH} 1-\mathrm{p} 1$ and $\mathrm{cH} 2-\mathrm{p} 1$. Also negatively charged amino acids aspartate and glutamate are far less than positively charged amino acids lysine, histidine, and arginine.

An ELISA assay was performed for all peptide candidates for cHSA-1, cHSA-2, and native HSA (control). In cHSA-1, ELISA assays of all phages were shown to have similar binding to cHSA-1, despite they have almost no sequence similarities (Figure 1). Among them, cH2-p1, cH2-p3, cH2-p4, cH2-p5, and $\mathrm{cH} 2$-p6 had significantly lower binding to HSA. In cHSA-2 ELISA (Figure 2), all phages were shown to be cHSA-2specific, with the absorbance difference between HSA and cHSA more significant than in cHSA-1 ELISA. Besides, $\mathrm{cH} 2$ p1 was also found to be with a higher binding affinity to cFgn compared to native Fgn as control (Figure 2).

2.3. Identification of Peptide Specific to cHSA through Isothermal Titration Calorimetry (ITC). ELISA results revealed that $\mathrm{cH} 2-\mathrm{p} 1, \mathrm{cH} 2-\mathrm{p} 3, \mathrm{cH} 2-\mathrm{p} 4, \mathrm{cH} 2-\mathrm{p} 5$, and cH2-p6 had specificity for cHSA-1 and cHSA-2. To further characterize their binding, and to minimize peptide-peptide interactions as opposed to peptide-protein interactions, the water-soluble peptides ( $\mathrm{cH} 2-\mathrm{p} 1, \mathrm{cH} 2-\mathrm{p} 4$, and $\mathrm{cH} 2-\mathrm{p} 6)$ were synthesized for ITC experiments. $\mathrm{cH} 2$-p3 and $\mathrm{cH} 2$-p5 were excluded as they would be marginally soluble within the aqueous solution.

ITC analysis of binding between $\mathrm{cH} 2-\mathrm{p} 1, \mathrm{cH} 2-\mathrm{p} 4, \mathrm{cH} 2-\mathrm{p} 6$, and cHSA or HSA yielded $K_{\mathrm{d}}$ values between $10^{-5}$ and $10^{-3} \mathrm{M}$

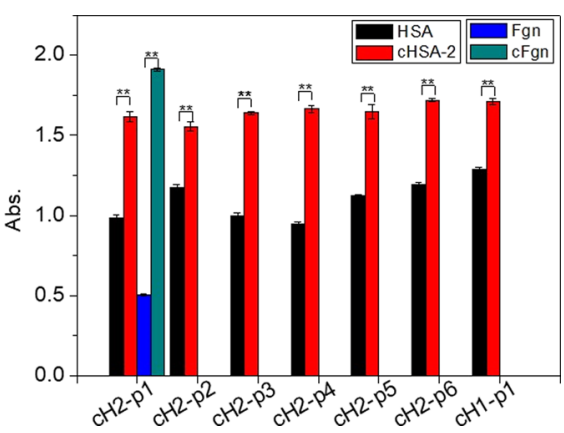

Figure 2. Affinity of candidate phages obtained through the phage display biopanning targeting cHSA to native HSA, carbamylated HSA (cHSA-2), Fgn, and carbamylated Fgn (cFgn) (data represent mean $\pm 1 \mathrm{SD}, n=3$; *, $p<0.01$; **, $p<0.001)$.

(Figures 3, Figure 4, and Figure 5). Previous work using disulfide-constrained cyclic peptide phage display libraries against HSA showed $K_{\mathrm{d}}$ values of $10^{-6}-10^{-5} \mathrm{M}$ (phosphatebuffered saline, PBS, $\mathrm{pH} 6.2$ ), where $K_{\mathrm{d}}$ increased dramatically at $\mathrm{pH}$ values of 7.4 and 9.4. ${ }^{32}$ In our work, we did not find any peptide binding to $\mathrm{HSA} / \mathrm{cHSA}$ with $K_{\mathrm{d}}$ less than $10^{-5} \mathrm{M}$, possibly because negative panning against HSA removed highHSA-affinity clones. The downward ITC titration peaks suggest that the binding process is exothermic. The ITC data followed the dimensionless parameter $c=[\mathrm{M}]_{0} / K_{\mathrm{d}}$, where $c \sim 1$. In cases like these, only $K_{\mathrm{d}}$ can be determined with a high degree of certainty, while the stoichiometry $(n)$ and binding enthalpy $(\Delta H)$ are considered uncertain and are therefore not reported. ${ }^{36,37}$ For $\mathrm{cH} 2$-p1, the interaction with HSA was too weak to produce an obvious titration curve (Figure 3a). Despite the fact it was possible to obtain a $K_{d}$ value of $1.0 \times 10^{-3} \mathrm{M}$ for $\mathrm{cH} 2-\mathrm{p} 1$ binding to HSA, the certainty of such a result is low due to a large confidence interval of $\pm 4.98 \times 10^{-4} \mathrm{M}$. However, $\mathrm{cH} 2$-p1 binding to cHSA yielded a typical low $c$ value nonsigmoidal titration curve, and a $K_{\mathrm{d}}$ value of $9.7 \times 10^{-5} \mathrm{M}$ was obtained with a low confidence interval of $\pm 3.1 \times 10^{-5} \mathrm{M}$. For $\mathrm{cH} 2$-p4 and $\mathrm{cH} 2$ p6, the titration curves to both HSA and cHSA are nonsigmoidal as well, with the $K_{\mathrm{d}}$ values between $10^{-5}$ and $10^{-4}$ M. cH2-p4 gave a lower $K_{d}$ for binding to HSA $(4.6 \times$ $\left.10^{-5} \mathrm{M}\right)$ than binding to cHSA $\left(1.3 \times 10^{-4} \mathrm{M}\right)$, and $\mathrm{cH} 2$-p6 showed a similar $K_{\mathrm{d}}$ for binding to HSA $\left(1.3 \times 10^{-4} \mathrm{M}\right)$ and cHSA $\left(2.0 \times 10^{-4} \mathrm{M}\right)$. As the main effect of carbamylation is the positive charge elimination, for HSA with a slightly negative charge, carbamylated samples shall have a more negative surface charge (Figure 6a). ${ }^{38}$ We also measured the $\mathrm{pI}$ value of cHSA through $\zeta$-potential as 4.13 , which was shifted

Table 2. Lists of Candidate Peptide Sequences Obtained through the Phage Display Biopanning Targeting cHSA

\begin{tabular}{|c|c|c|c|c|c|}
\hline sequence & frequency $(\%)^{a}$ & $\mathrm{pI}^{b}$ & target & label & reference \\
\hline GSAARTISPSLL & 11.9 & 9.75 & cHSA-2 & $\mathrm{cH} 2-\mathrm{p} 1$ & 47 \\
\hline FNHKHNFTDSAH & 6.0 & 7.02 & cHSA-2 & $\mathrm{cH} 2-\mathrm{p} 2$ & this work \\
\hline WPARTSAPFTNS & 6.0 & 9.75 & cHSA-2 & $\mathrm{cH} 2-\mathrm{p} 3$ & this work \\
\hline AHPHSDKLVPPR & 3.6 & 8.8 & cHSA-2 & $\mathrm{cH} 2-\mathrm{p} 4$ & 47 \\
\hline TPTIAIAQYNKW & 2.4 & 8.26 & cHSA-2 & $\mathrm{cH} 2-\mathrm{p} 5$ & this work \\
\hline TLGLRPVPVATT & 1.2 & 9.41 & cHSA-2 & $\mathrm{cH} 2-\mathrm{p} 6$ & 47,48 \\
\hline APPHVSSTVSWL & 100 & 6.79 & cHSA-1 & $\mathrm{cH} 1-\mathrm{p} 1$ & this work \\
\hline
\end{tabular}

${ }^{a}$ The frequency was the percentage of the sequences appeared in sequencing data from all rounds of biopanning, with the sum of 36 and 61 sequences for biopanning against cHSA-1 and cHSA-2, respectively. ${ }^{b}$ The isoelectric point (pI) value of peptide was given by ProtParam tool for protein analysis. $^{39}$ 

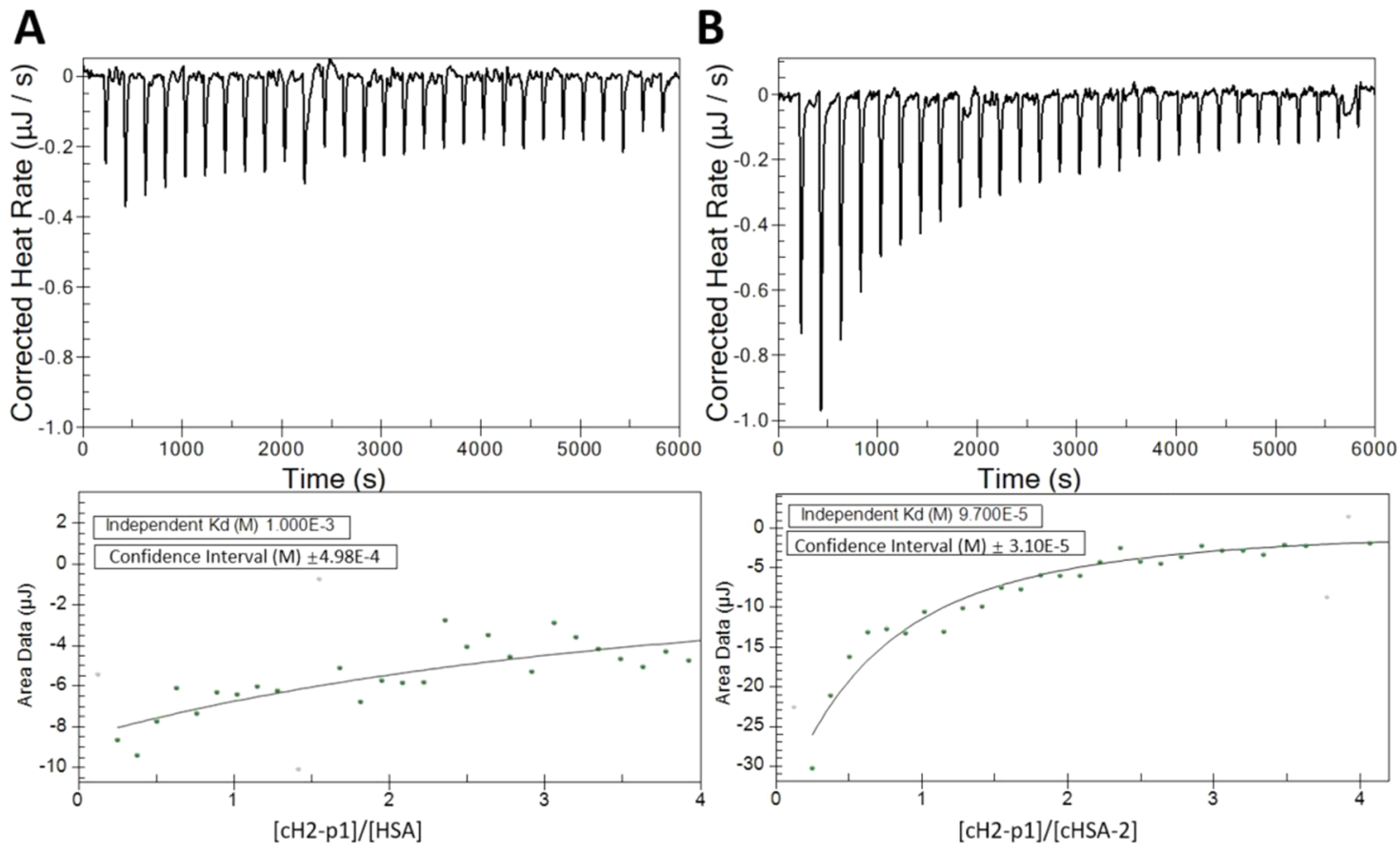

Figure 3. ITC raw titration data and fitting of integrated heat plots of peptide cH2-p1 titration into (A) native HSA and (B) cHSA-2.

A
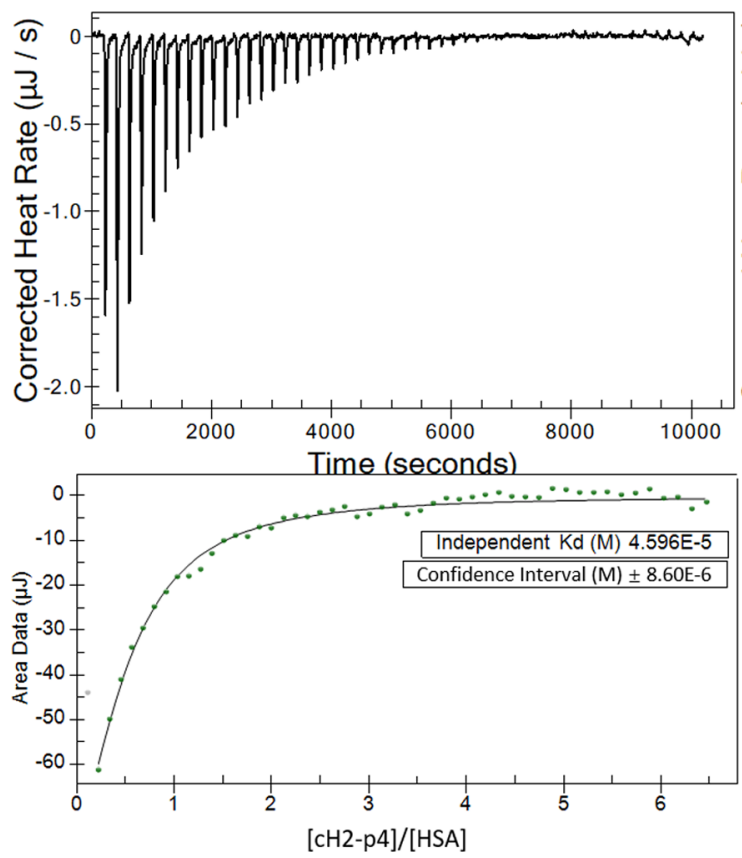

B
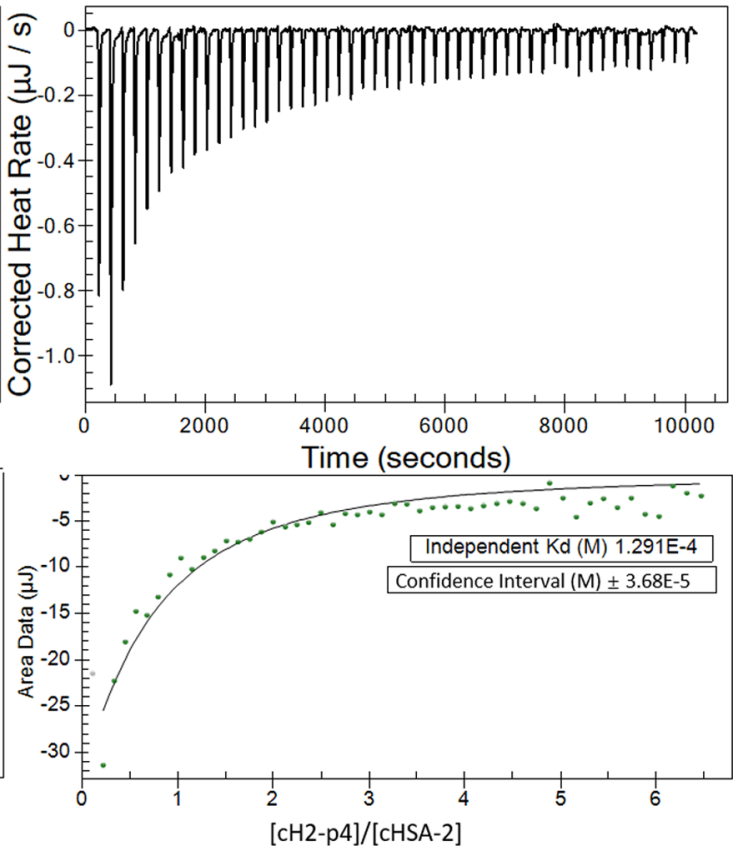

Figure 4. ITC raw titration data and fitting of integrated heat plots of peptide $\mathrm{cH} 2$-p4 titration into (A) native HSA and (B) cHSA-2.

from 4.83 for native HSA (Figure $6 \mathrm{~b}$ ). Therefore, electrostatic interaction may have an impact on the peptide binding to cHSA. The pI's of p1, p4, and p6 were calculated (ProtParam) to be $9.75,8.8$, and 8.26 , respectively, ${ }^{39}$ indicating they are positively charged at $\mathrm{pH}$ 7.4. However, despite the fact that cH2-p1 has a higher pI than $\mathrm{cH} 2-\mathrm{p} 4, \mathrm{cH} 2-\mathrm{p} 1$ did not give a lower $K_{\mathrm{d}}$ when binding to native HSA. This indicates that the interaction between $\mathrm{cH} 2-\mathrm{p} 1$ and $\mathrm{HSA} / \mathrm{cHSA}$ is not only affected by electrostatic interactions.

$\mathrm{cH} 2$-p1 seems to be the best candidate peptide for binding cHSA. $\mathrm{cH} 2$-p 1 showed a consistently higher binding affinity for
cHSA than HSA in both ITC and ELISA results. However, a similar level of binding specificity for $\mathrm{cH} 2-\mathrm{p} 4$ or $\mathrm{cH} 2-\mathrm{p} 6$ was not observed in ITC results. This may arise from the fact that the phage-displayed peptides are constrained in how they interact with cHSA as their C-terminals are coupled to the phage. Thus, synthesized peptides have one additional negative carboxylate compared to the phage-bound peptides, which may show different binding properties as a function of electrostatic properties. Moreover, ELISA results involved binding HSA/ cHSA to a surface, which may have caused structural rearrangement of the protein and thus altered how the phage 


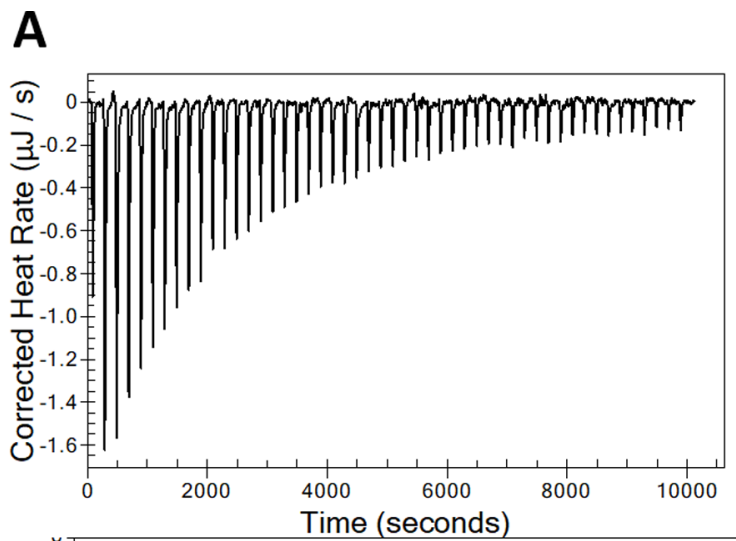

\section{B}
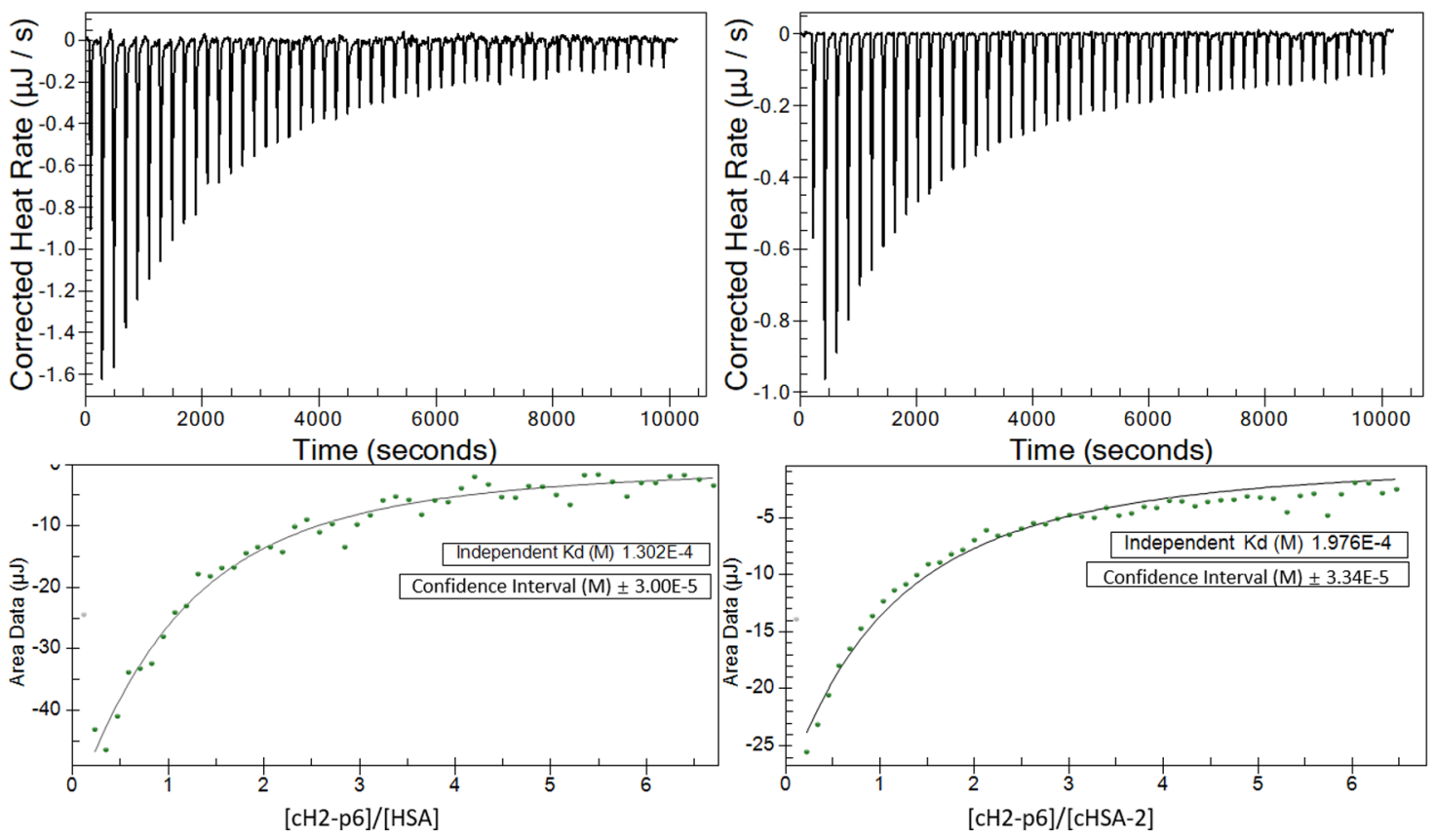

Figure 5. ITC raw titration data and fitting of integrated heat plots of peptide $\mathrm{cH} 2$-p6 titration into (A) native HSA and (B) cHSA-2.
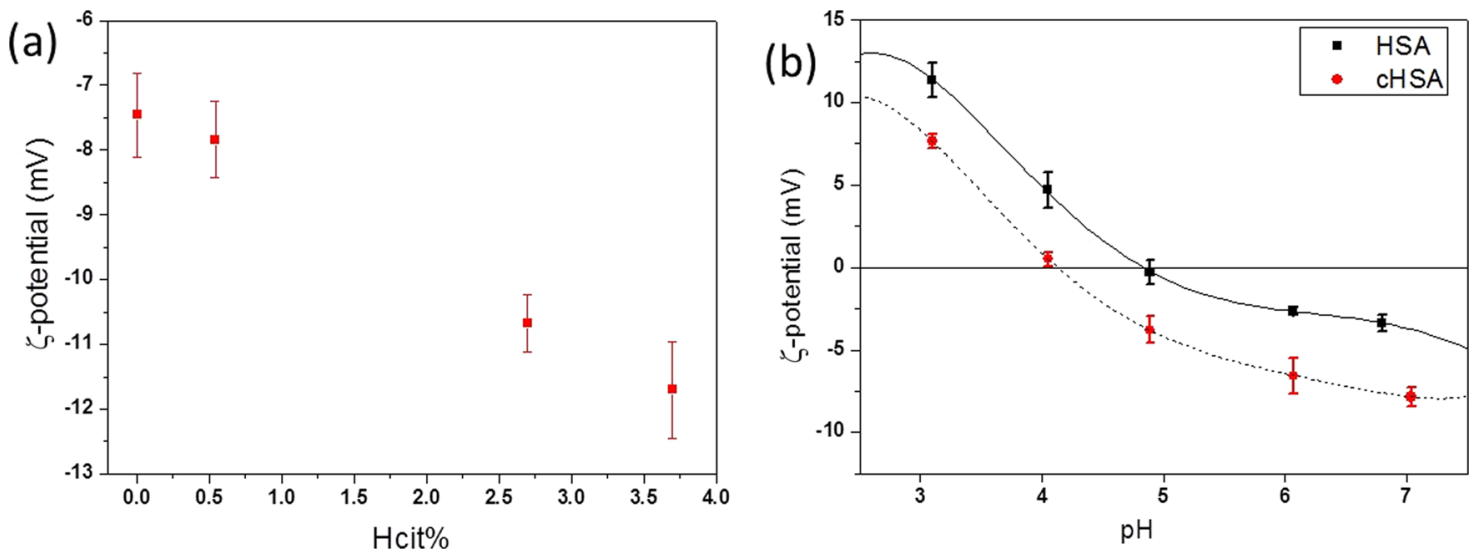

Figure 6. (a) $\zeta$-Potential and (b) isoelectric point of native HSA and carbamylated HSA.

interacted with it compared to ITC experiments where a fraction of the protein would not be adsorbed to the walls of the test cell.

2.4. $\mathrm{cH} 2-\mathrm{p} 1$ Binding to cHSA with Different Hcit\%. Since the interaction between $\mathrm{cH} 2$-p1 and cHSA was shown to be specific, it is interesting to know if affinity is affected by the extent of carbamylation. To this end, binding of $\mathrm{cH} 2-\mathrm{p} 1$ to cHSA-1, cHSA-2, and cHSA-3 proteins with low to high Hcit\% had $K_{\mathrm{d}}$ values of $1.2 \times 10^{-4}, 9.7 \times 10^{-5}$, and $9.9 \times 10^{-5} \mathrm{M}$, respectively (Figure 7 ). Although the $\zeta$-potential of cHSA shifted from $-7.84 \mathrm{mV}$ for cHSA-1 to $-11.7 \mathrm{mV}$ for cHSA-3 (Table 1 and Figure 6a), that difference in surface charge did not seem to affect the binding affinity of $\mathrm{cH} 2$-p1. The similar $K_{\mathrm{d}}$ values may indicate that the ligand binding may be specific to homocitrulline.

2.5. cH2-p1 Binding to cFgn. One previous study collected sera from rabbits inoculated with cHSA and revealed that such sera contained antibodies that recognized homocitrulline-containing collagen telopeptides. ${ }^{20}$ To verify if $\mathrm{cH} 2-\mathrm{p} 1$ is homocitrulline-specific, regardless of protein it may be conjugated to, $\mathrm{cH} 2$-p1 binding to native and carbamylated Fibrinogen (Fgn) was tested (Figure 8). For cH2-p1 binding to Fgn, we found no exothemic or endothemic peaks generated during the whole titration, seeming to indicate that no affinity existed between Fgn and this peptide. While for $\mathrm{cH} 2-\mathrm{p} 1$ binding to cFgn the titration was endothermic with strong titration peaks, with a model $K_{d}$ value of $8.4 \times 10^{-5} \mathrm{M}$. The result of $\mathrm{cH} 2$-p1 titration to Fgn showed $\mathrm{cH} 2$-p1 does not bind to this protein without carbamylation. Unlike cHSA, binding of $\mathrm{cH} 2$-p1 to cFgn was found to be endothemic, which suggests that the binding is entropy-driven. The Hcit\% for cFgn was measured to be $12.0 \%$, yet still with similar $K_{\mathrm{d}}$ for binding to $\mathrm{cH} 2$-p1 compared to cHSA. The endothermic binding may involve complex conformational change that may require further study to determine the mechanism involved.

2.6. Binding Mechanism Study through Titration of cH2-p1 to cHSA with Anti-Hcit. To study if the binding sites on cHSA for $\mathrm{cH} 2$-p1 are the same for antibody targets 

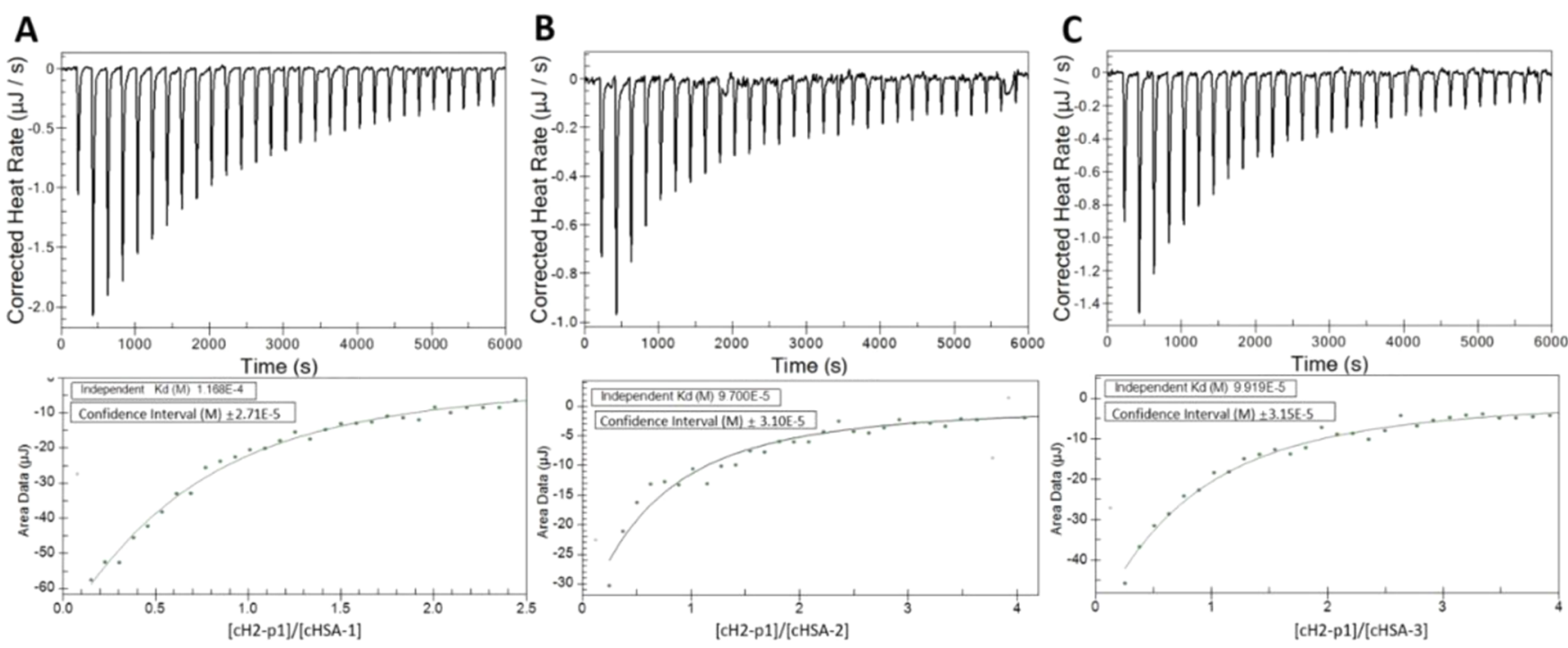

Figure 7. ITC raw titration data and fitting of integrated heat plots of peptide cH2-p1 titration into (A) cHSA-1, (B) cHSA-2, and (C) cHSA-3.

A
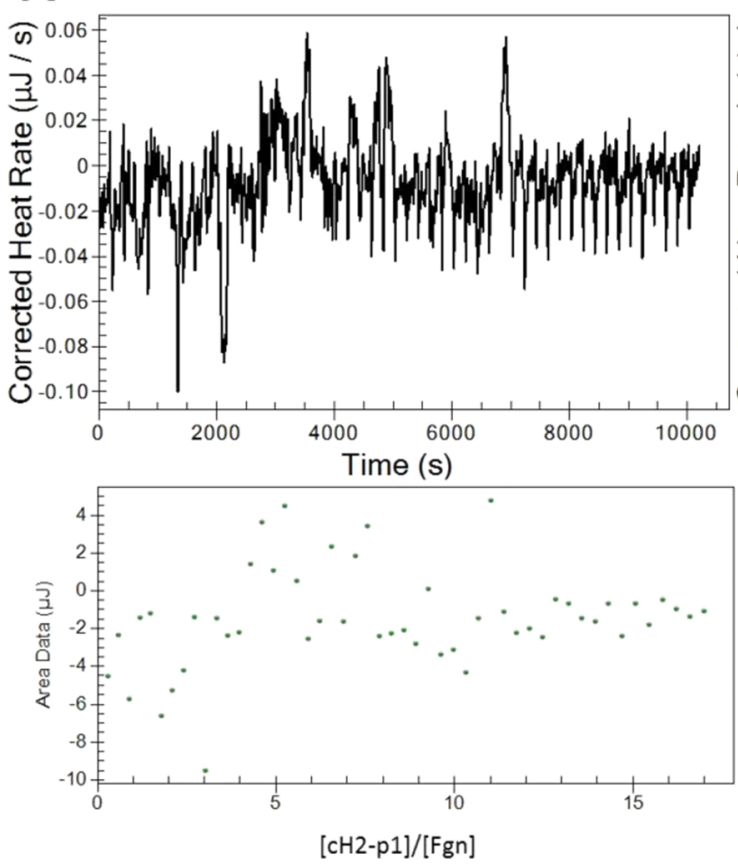

B
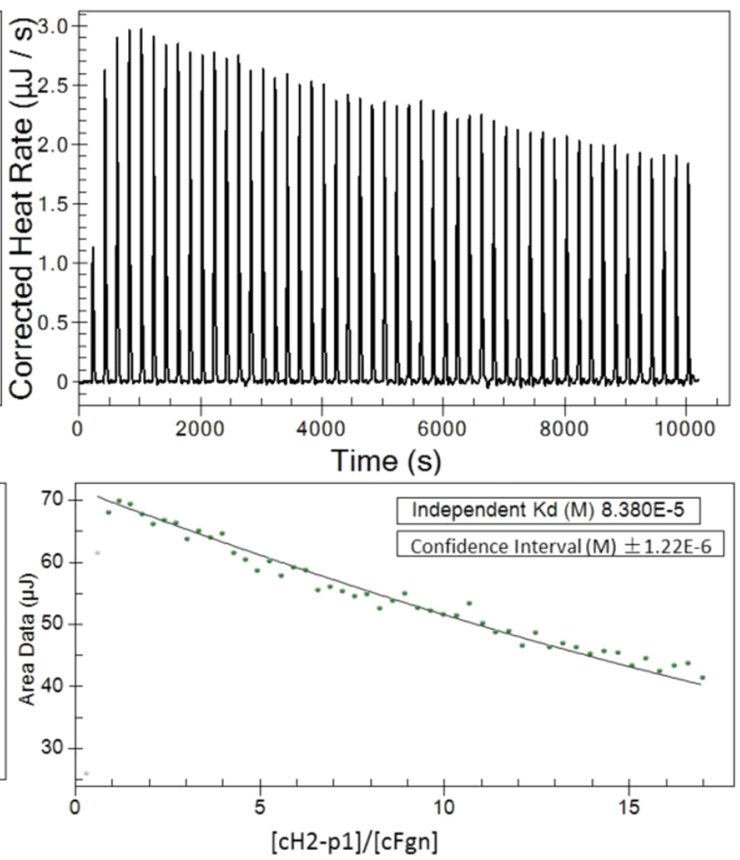

Figure 8. ITC raw titration data and fitting of integrated heat plots of peptide $\mathrm{cH} 2$-p1 titration into (A) native Fgn and (B) cFgn.

homocitrulline, cHSA was incubated with anti-Hcit prior to $\mathrm{cH} 2$-p1 titration test. The control test was done by titration of $\mathrm{cH} 2$-p1 into the solution containing only anti-Hcit, and the result (Figure S4) proved that $\mathrm{cH} 2$-p1 has a very low binding affinity toward anti-Hcit, with the $K_{\mathrm{d}}$ fitted to be $1 \times 10^{-3} \mathrm{M}$; therefore, the interaction between $\mathrm{cH} 2$-p1 and antibody is not to be considered in later tests. To fit the titration data for $\mathrm{cH} 2$ p1 to cHSA with and without the presence of anti-Hcit, a fixed $K_{\mathrm{d}}$ of $9.7 \times 10^{-5} \mathrm{M}$ as we determined before for $\mathrm{cH} 2$-p1 titrated into cHSA was used, and good fitting results were obtained for both cases (Figure 9). To accommodate the low concentration of obtained antibody, the concentration of both cHSA and cH2-p1 have been lowered by 10 times, thus resulting in a lower $c$ value and more linear and flatter fitting curve. Nevertheless, a difference was found on binding enthalpy, that the binding enthalpy is less for $\mathrm{cH} 2-\mathrm{p} 1$ to cHSA when anti-Hcit is present. However, due to the low c binding nature, the binding enthalpy cannot be precisely quantified. If we assume that the $\mathrm{cH} 2$-pl targets the same binding sites with anti-Hcit, it is reasonable to regard the difference as the result of decreased $n$ value due to the occupancy of binding sites by anti-Hcit.

2.7. Binding Mechanism Study through Molecular Docking. Since $\mathrm{cH} 2$-p1 binds to both cHSA and cFgn with high affinity, we assume that $\mathrm{cH} 2$-p1 has the binding site for homocitrulline residues. To explore the possible binding mode of homocitrulline, molecular docking was studied. The model ligand Hcit-res instead of its amino acid form was created to simulate the carbamylated lysine residue as a simplification. The peptide chain of Hcit-res was simplified with two peptide 


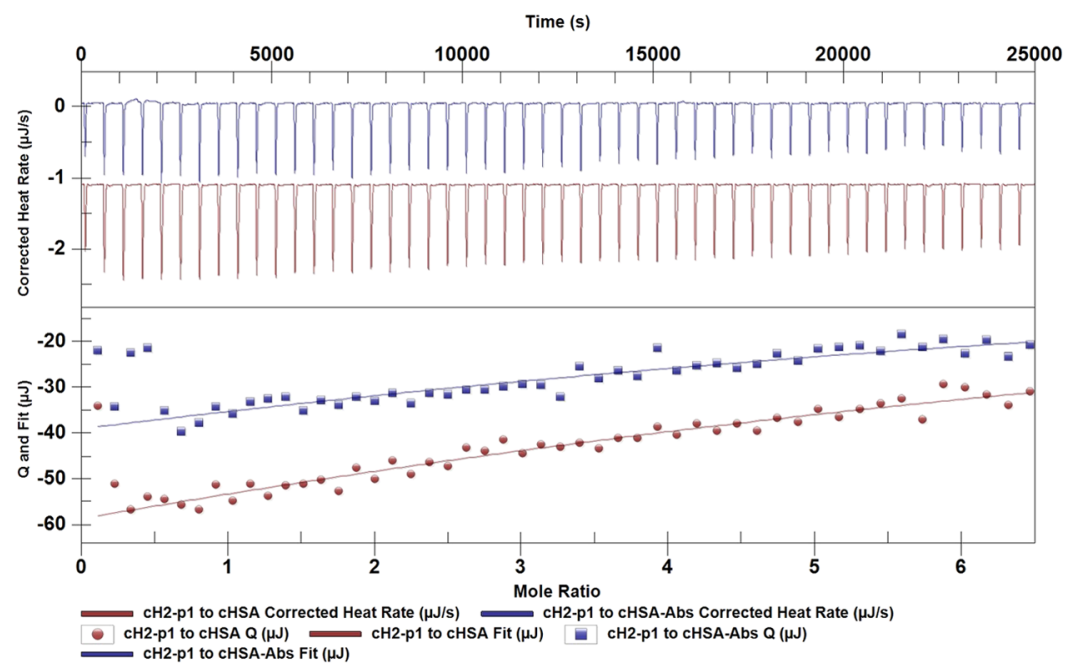

Figure 9. ITC raw titration data and fitting of integrated heat plots of peptide cH2-p1 titration into cHSA with cHSA-Abs and without cHSA been incubated with anti-Hcit.

(a)

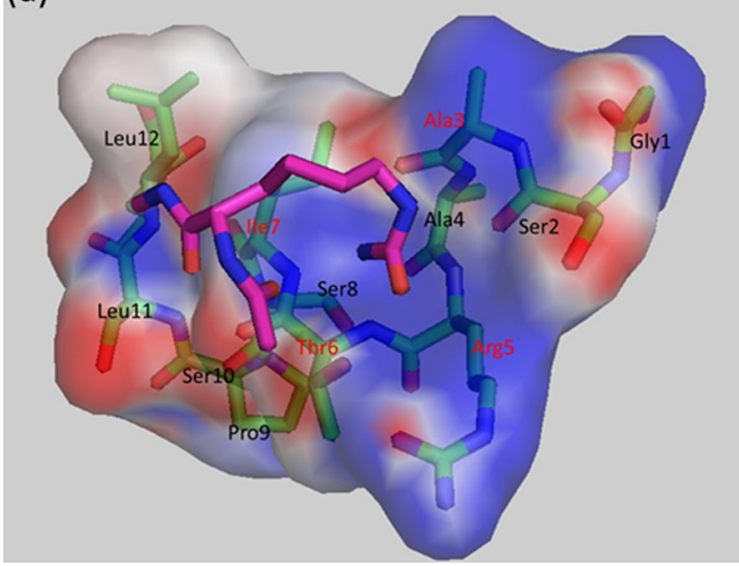

(b)

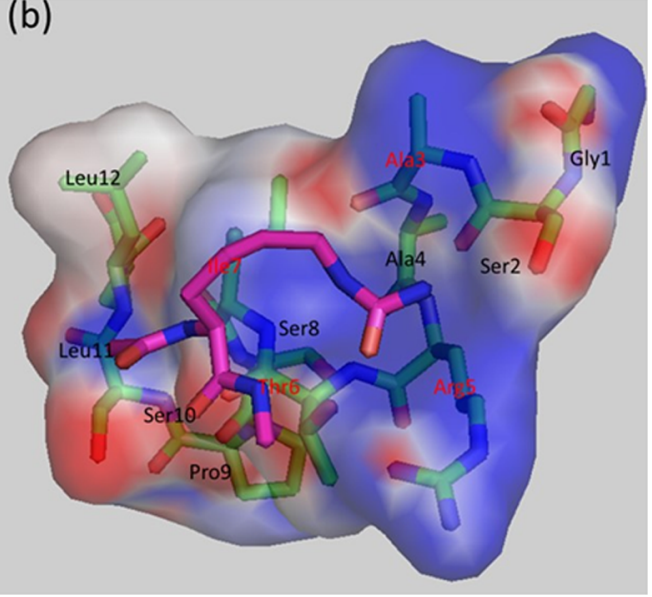

Figure 10. Two ways, (a) pose a and (b) pose b, of docking the designed model Hcit-res (Pink carbon chain) into the candidate pocket of cH2-p1 (green carbon chain) by AutoDock Vina. The surface of $\mathrm{cH} 2-\mathrm{p} 1$ is shown with an electrostatic potential map.

bonds terminated with methyl groups. Longer peptide chains are not preferable as they may require a larger box for docking and reduce the site specificity. With the purpose to search for the best pose of the side chain and avoid trapping of peptide chains into binding pockets, all non-side-chain bonds of Hcitres were set to be non-rotatable and only the side-chain bonds were allowed to be rotatable. ${ }^{40}$ The top-ranked binding site cH2-p1-C1 is composed of four residues, Ala3, Arg5, Thr6, and Ile7. Figure 10 shows the top 2 scored poses, with the binding affinity of $-3.1 \mathrm{kcal} / \mathrm{mol}$ for both conformations. Since the surface of pocket is mainly low electrostatic potential area, docking of carbamoyl group-containing ligand should be expected. The same affinity score for both poses suggests that they are equally favorable. Pose a has the primary amine buried inside the pocket, and pose $b$ has the secondary amine buried inside the pocket. Since the positively charged Arg5 is involved in the binding pocket, docking of lysine residues should not be considered as favorable as homocitrulline residues. Although it is possible that homocitrulline residues may dock into other binding sites, by doing docking experiments on all other two potential binding pockets provided by I-TASSER, we found that none of the top-scored poses are reasonable with homocitrulline side chain docked into the pocket.
Based on all results obtained above, the avidity of $\mathrm{cH} 2-\mathrm{p} 1$ to carbamylated proteins was significantly higher than to the native protein. However, it is still relatively low compared to antibody binding of even native HSA. This could arise from the fact that according to the molecular docking result, only four residues in $\mathrm{cH} 2-\mathrm{p} 1$ are involved in binding of homocitrulline to form a binding pocket. This limited interaction between peptide amino acids and the small fraction of homocitrulline residues trapped inside may present the maximum limit of the binding affinity-short of further engineering of the amino acids involved in binding homocitrulline.

\section{CONCLUSIONS}

Several peptide sequences were identified using a Ph.D.-12 phage display library against carbamylated HSA. ELISA results revealed that the phage clone obtained through biopanning on cHSA-1 might be a TUP and does not have a significantly high binding specificity, while several phage clones obtained from cHSA-2 biopanning showed high binding specificity to both cHSA-1 and cHSA-2. ITC results were used to identify GSAARTISPSLL (cH2-p1) to have a dissociation constant $\left(K_{d}\right)$ of $9.7 \times 10^{-5} \mathrm{M}$ during exothermic binding to cHSA, and was almost 1 order of magnitude lower than its $K_{\mathrm{d}}$ to native 
HSA. The binding affinity for $\mathrm{cH} 2$-p 1 toward cHSA was not found to be influenced by the extent of carbamylation. Moreover, $\mathrm{cH} 2-\mathrm{p} 1$ was found to bind $\mathrm{cFgn}$ over the native protein. This process was endothermic, but yielded a similar $K_{d}$ $\left(8.4 \times 10^{-5} \mathrm{M}\right)$ as that for cHSA binding. The binding of $\mathrm{cH} 2-$ p1 to cHSA was weakened when anti-Hcit is present in cHSA solution, suggesting that anti-Hcit occupied the same sites where $\mathrm{cH} 2$-p 1 binds to cHSA. Through molecular docking study, we identified two poses homocitrulline residues may have when docking into the $\mathrm{cH} 2$-p1 pocket. The potential of $\mathrm{cH} 2$ - 1 to bind carbamylated proteins over native ones is the baseline for looking at removal of these proteins from CKD patients for further treatment.

\section{EXPERIMENTAL SECTION}

4.1. Materials. Albumin from human serum (HSA, lyophilized, fatty-acid-free) and fibrinogen from bovine plasma (Fgn, $\geq 75 \%$ clottable) were purchased from Sigma-Aldrich (Canada). Sodium cyanate, 2-aminobenzoic acid (ABA), trichloroacetic acid (TCA), and sodium tetraborate (ST) were also provided by Sigma-Aldrich (Canada). Amicon ultra15 centrifugal filter unit was provided by Millipore Sigma. M13KE phage display kit (Ph.D-12) was provided by New England Biolabs. Homocitrulline/Citrulline Assay Kit was provided by Cell Biolabs for quantification of carbamylation. Anti-carbamylation (homocitrulline) polyclonal antibody (anti-Hcit), obtained by immunizing rabbits with carbamylated protein, was provided by Cayman Chemical. QIAprep Spin M13 Kit was provided by QIAGEN for template purification. Anti-M13 Antibody (HRP) (Mouse Monoclonal antibody) was provided by Sino Biological. ELISA Substrate Solution (1Step Ultra TMB) was provided by Thermo Fisher Scientific. Protein targets used were filter-sterilized before biopanning, and all solutions or supplies used in biopanning were autoclaved in advance. Sodium dodecyl sulfate-polyacrylamide gel electrophoresis (SDS-PAGE) precast gels (10\% MiniPROTEAN TGX stain-free protein gels) and protein standard ladder (Precision Plus Protein Dual Color Standards) were provided by Bio-Rad. All candidate peptides without group protection were synthesized by GL Biochem, and the purity was verified by high-performance liquid chromatography (HPLC) with 98\%, and the composition was confirmed by mass spectrometry.

4.2. In Vitro Carbamylation of HSA. In vitro carbamylation of HSA and Fgn was done as reported before. ${ }^{27}$ In brief, HSA carbamylation was carried out by incubating HSA sample $(0.6 \mathrm{mM})$ under $0.1 \mathrm{M}$ phosphate buffer $(\mathrm{PB}, \mathrm{pH}$ 7.4) with sodium cyanate at room temperature with stirring for 8 days, and Fgn carbamylation was carried out by incubating the Fgn sample $(0.008 \mathrm{mM})$ under $0.1 \mathrm{M}$ phosphate buffer $(\mathrm{PB}, \mathrm{pH}$ 7.4) with sodium cyanate $(0.1 \mathrm{M})$ at room temperature with stirring for 2 days. The initial concentration of sodium cyanate was varied for different degrees of carbamylation of cHSA. Unbound free cyanate was removed by three cycles of ultrafiltration with $\mathrm{PB}$. ABA assay, as reported elsewhere, was used to prove the absence of residual cyanate. $^{41}$ In brief, $0.5 \mathrm{~mL}$ of solution that may contain residual cyanate was added into a solution of $6 \mathrm{~N} \mathrm{HCl}$ with 2aminobenzoic acid for $1 \mathrm{~min}$ in boiling water bath and then cooled to room temperature, and the absorbance at $310 \mathrm{~nm}$ was recorded for quantification of residual cyanate. The solution protein concentration was determined using UV-vis spectroscopy from absorbance at $280 \mathrm{~nm}$ and was then diluted to desired concentrations. The extent of carbamylation was quantified by the percentage of carbamylated lysine, marked as Hcit\%, and was measured through homocitrulline assay following manufacturer's protocol. In brief, the samples were treated with Proteinase $\mathrm{K}$ in the presence of SDS at $37^{\circ} \mathrm{C}$ for 2 $\mathrm{h}$ and then incubated with a urea-nitrogen reagent and diacetyl monoxime at $97{ }^{\circ} \mathrm{C}$ for $30 \mathrm{~min}$. Precipitates were removed by centrifugation at $18000 \mathrm{~g}$ for $10 \mathrm{~min}$, and the supernatant was transferred into a 96-well plate and analyzed at $550 \mathrm{~nm}$ with a plate reader. A standard curve of homocitrulline solution provided in the kit $(0$ to $600 \mu \mathrm{M})$ was made for the determination of homocitrulline in the sample. Hcit\% was calculated by dividing the measured homocitrulline with the total lysine amount estimated (59 for one HSA molecule, 208 for one Fgn molecule).

4.3. Protein Characterization. The size and $\zeta$-potential for both HSA and cHSA were measured through Malvern Nano-ZS DLS. For $\zeta$-potential measurement, protein solution was concentrated to $8 \mathrm{mg} / \mathrm{mL}$ with $1 \mathrm{mM} \mathrm{PB}(\mathrm{pH} 7.4)$. For size measurement, protein solution was diluted to $0.25 \mathrm{mg} / \mathrm{mL}$ with $0.1 \mathrm{M} \mathrm{PB}$ ( $\mathrm{pH} 7.4$ ). All measurements were taken at 25 ${ }^{\circ} \mathrm{C}$, and each reported data represents average of three measurements. To verify the structure integrity of HSA after carbamylation, SDS-PAGE was performed on a Bio-Rad miniprotean electrophoresis system. The test was done following the standard protocol provided by Bio-Rad. In brief, both HSA and CHSA solutions were denatured by mixing with SDS and heating at $60{ }^{\circ} \mathrm{C}$ for $5 \mathrm{~min}$. After loading samples into wells of a precast gel, electrophoresis was performed at $200 \mathrm{~V}$ for $\sim 30$ min. The gel was stained with $0.2 \%$ Coomassie Brilliant Blue, followed by destaining in acetic acid solution.

4.4. Biopanning against cHSA. Six wells of a 96-well ELISA passive binding plate were filled with cHSA target (100 $\mu \mathrm{g} / \mathrm{mL}$ in $0.1 \mathrm{M}$ carbonate buffer, $\mathrm{pH} 8.6$ ) with $150 \mu \mathrm{L}$ each well. The plate was incubated in a moisture environment at 4 ${ }^{\circ} \mathrm{C}$ overnight, followed by discarding that target solution and refilling fully with HSA blocking $(5 \mathrm{mg} / \mathrm{mL}$ in $0.1 \mathrm{M}$ carbonate buffer, $\mathrm{pH}$ 8.6) buffer for another $1 \mathrm{~h}$ at $4{ }^{\circ} \mathrm{C}$. Prior to binding to target, the phage library was first screened on HSA for negative panning. The phage library was prepared at $10^{11} \mathrm{pfu} /$ $\mathrm{mL}$ in TBST, and was added by pipetting $100 \mu \mathrm{L}$ into wells preblocked with HSA only. After incubation for $1 \mathrm{~h}$ at room temperature, the library solution was transferred to the plate with target, and was incubated for another $1 \mathrm{~h}$ with gentle shaking. Unbound phages were removed by washing the wells with TBST-0.1\% 10 times, and the tween concentration was increased to $0.5 \%$ after the first round. Surface-bound phages were eluted with $100 \mu \mathrm{L}$ of glycine elution buffer $(\mathrm{pH} 2.2$, containing $1 \mathrm{mg} / \mathrm{mL} \mathrm{HSA}$ ) for $15 \mathrm{~min}$ and were neutralized with Tris- $\mathrm{HCl}$ buffer $(\mathrm{pH}$ 9.1). Elution was performed three times for each well, and the collected eluates were denoted as E1, E2, and E3.

4.5. Phage Amplification and Purification. With a 250 $\mathrm{mL}$ Erlenmeyer flask, $20 \mathrm{~mL}$ of E. coli early log $\left(\mathrm{OD}_{600} 0.01-\right.$ $0.05)$ culture was mixed with $500 \mu \mathrm{L}$ of each eluate and was incubated for $4.5 \mathrm{~h}$ at $37{ }^{\circ} \mathrm{C}$ with vigorous shaking. Bacteria were then separated by centrifuging at $12000 \mathrm{~g}$ for $10 \mathrm{~min}$. The supernatant was collected and stored at $4{ }^{\circ} \mathrm{C}$ overnight, with addition of $1 / 6$ volume of $\mathrm{PEG} / \mathrm{NaCl}$ to precipitate the phage. The precipitate was then centrifuged and further purified by redissolving in $1 \mathrm{~mL}$ of tris buffered saline (TBS) and precipitating again with $0.167 \mathrm{~mL}$ of $\mathrm{PEG} / \mathrm{NaCl}$. The purified pellet was redissolved in $200 \mu \mathrm{L}$ of TBS and stored at $4{ }^{\circ} \mathrm{C}$. 

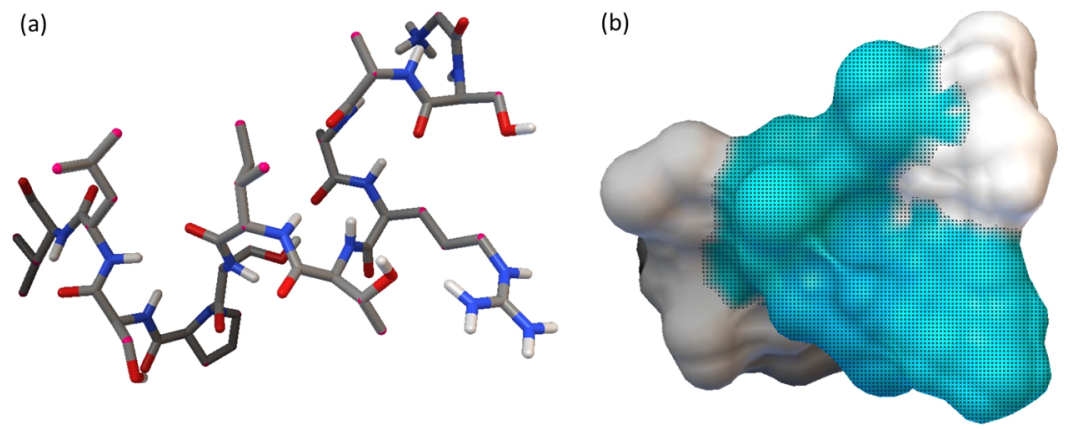

Figure 11. (a) Modeling conformation of cH2-p1. (b) Top-ranked potential binding site, cH2-p1-C1, of cH2-p1.

4.6. Phage Titration. Each amplified eluate was titrated with the blue plague titration method given in the supplier's manual. In brief, $200 \mu \mathrm{L}$ of E. coli middle log $\left(\mathrm{OD}_{600} \sim 0.5\right)$ culture was mixed with $10 \mu \mathrm{L}$ of eluate (10-fold serial dilution in TBS in the range of $\left.10^{8}-10^{14}\right)$ and $790 \mu \mathrm{L}$ of melted top agar and poured onto a prewarmed LB/IPTG/Xgal plate. All plates were incubated at $37^{\circ} \mathrm{C}$ overnight, and the blue plagues were counted as plaque-forming units ( $\mathrm{pfu}$ ).

4.7. Phage Clone Separation and Template Isolation for Sequencing. For single-clone phage collection, each separate blue plague for amplified eluate was picked and suspended into $100 \mu \mathrm{L}$ of TBS in a 96-well plate. The plate was heated at $60{ }^{\circ} \mathrm{C}$ for $45 \mathrm{~min}$ for sterilization. By mixing with $50 \mu \mathrm{L}$ of $80 \%$ glycerol, each phage suspension was stored at $-20{ }^{\circ} \mathrm{C}$. The single-stranded phage DNA was isolated with the QIAprep Spin M13 Kit following supplier's manual. In brief, each single-clone phage suspension was amplified by adding 10 $\mu \mathrm{L}$ into $4 \mathrm{~mL}$ of $E$. coli early $\log \left(\mathrm{OD}_{600} 0.01-0.05\right)$ culture and incubating for $4 \mathrm{~h}$ at $37^{\circ} \mathrm{C}$. After removing bacteria by centrifuge, $1 / 100$ volume of buffer MP was added to each phage supernatant to incubate for $2 \mathrm{~min}$, and a total of $2.1 \mathrm{~mL}$ of phage solution was loaded into QIAprep spin column and centrifuged to flow-through the column. To enable M13 phage lysis and template purification, $0.7 \mathrm{~mL}$ of buffer $\mathrm{PB}$ was loaded into the column and flow-through by centrifuge, followed by $0.7 \mathrm{~mL}$ buffer PE loading and flow-through by centrifuge. The template was eluted by loading $100 \mu \mathrm{L}$ of EB. After incubating for $10 \mathrm{~min}$, the eluate was collected by centrifuge. The template concentration $(20-80 \mathrm{ng} / \mu \mathrm{L})$ and purity were verified by a NanoDrop UV-vis spectrophotometer in its ssDNA measurement mode. For sequencing, $10 \mu \mathrm{L}$ of each template was mixed with $1 \mu \mathrm{L}$ of -96 gIII sequencing primer, and the template sequence was obtained through standard Sanger DNA sequencing.

4.8. ELISA of Selected Phage Clones. To each well of an ELISA 96-well passive binding plate, $300 \mu \mathrm{L}$ of protein of interest $(1 \mathrm{mg} / \mathrm{mL}$ in $0.1 \mathrm{M}$ carbonate buffer, $\mathrm{pH} 8.6)$ was added and was incubated in a moist environment at $4{ }^{\circ} \mathrm{C}$ overnight, followed by discarding protein solution and refilling fully with TBST- $0.5 \%$ blocking buffer for another $1 \mathrm{~h}$ at $4{ }^{\circ} \mathrm{C}$. After washing the wells with TBST-0.5\% to remove unbound protein, $20 \mu \mathrm{L}$ of amplified single-clone phage solution $\left(10^{13}\right.$ $\mathrm{pfu} / \mathrm{mL}$ ) was added with $180 \mu \mathrm{L}$ of TBST- $0.5 \%$ buffer and was incubated for $2 \mathrm{~h}$. After washing the wells with TBST-0.5\% to remove unbound phages, $200 \mu \mathrm{L}$ of TBST- $0.5 \%$ containing 1 $\mu \mathrm{L}$ of HRP-Anti-M13 $(0.55 \mu \mathrm{g} / \mathrm{mL})$ was added to each well and was incubated for $1 \mathrm{~h}$. After washing the wells with TBST$0.5 \%$ to send away unbound antibodies, $100 \mu \mathrm{L}$ of HRP substrate was added to each well and was incubated for $10 \mathrm{~min}$.
The reaction was quenched by adding $100 \mu \mathrm{L}$ of $1 \mathrm{M} \mathrm{H}_{2} \mathrm{SO}_{4}$, and the absorbance at $450 \mathrm{~nm}$ was collected.

4.9. Isothermal Titration Calorimetry (ITC). The ITC experiment was performed on a Nano ITC low-volume isothermal titration calorimeter (TA Instruments) with an active cell volume of $170 \mu \mathrm{L}$ and an injection syringe volume of $50 \mu \mathrm{L}$. All proteins and peptides were dissolved using the 0.1 $\mathrm{M}$ sodium phosphate buffer ( $\mathrm{pH} 7.4$ ). For titration of HSA/ cHSA, the protein concentration was $0.1 \mathrm{mM}$ and the peptide concentration was $2 \mathrm{mM}$. For titration of Fgn/cFgn, the protein concentration was $4 \mu \mathrm{M}$ and the peptide concentration was $0.21 \mathrm{mM}$. Titration was performed with 50 consecutive injections of $0.95 \mu \mathrm{L}$ of peptide solution with $200 \mathrm{~s}$ spacing between each injection. For titration of the peptide into cHSA with antibody, cHSA was incubated with anti-Hcit for $2 \mathrm{~h}$ at 25 ${ }^{\circ} \mathrm{C}$ before titration, and both tirant and titrate solutions were prepared with $0.01 \mathrm{M}$ PBS ( $\mathrm{pH} 7.4$ ) containing $50 \%$ glycerol and $0.02 \% \mathrm{NaN}_{3}$. The stirring rate and isotherm temperature were set at $150 \mathrm{rpm}$ and $25{ }^{\circ} \mathrm{C}$, respectively. The ITC data were processed by NanoAnalyze Data Analysis v3.10.0 for baseline subtraction and model fitting (independent model). The heat of peptide dilution was subtracted from signal by doing control titration tests. All data were repeated at least twice, and the data presented is a representative curve since only very small variations among repeats were observed. The fitted curves were analyzed through the statistical test program. The Gaussian distribution of results was obtained through repeated simulation with controlled random data perturbations for 1000 trials, and the $95 \%$ confidence interval was given and is shown in the fitting graph.

4.10. Sodium Dodecyl Sulfate-Polyacrylamide Gel Electrophoresis (SDS-PAGE). SDS-PAGE was performed on a Bio-Rad mini-protean electrophoresis system. The test was done following the standard protocol provided by Bio-Rad. In brief, protein samples were denatured by mixing with SDS and heating at $60{ }^{\circ} \mathrm{C}$ for $5 \mathrm{~min}$. After loading samples into wells of a precast gel, electrophoresis was performed at $200 \mathrm{~V}$ for $\sim 30$ min. The gel was stained with $0.2 \%$ Coomassie Brilliant Blue, followed by destaining in acetic acid solution.

4.11. Molecular Docking. Structure of $\mathrm{cH} 2-\mathrm{p} 1$ was created through I-TASSER Protein Structure and Function Prediction Services (Figure 11a). ${ }^{42-44}$ The potential binding sites for this predicted model were also provided in the result. A total of three possible binding sites were determined, with the top binding site (marked as $\mathrm{cH} 2-\mathrm{p} 1-\mathrm{C} 1$, and the surface is shown by the blue area in Figure $11 \mathrm{~b}$ ) showing significantly higher C-score $^{45}$ (0.33) compared to the other two, 0.14 and 0.13 . To simulate the homocitrulline residue present in protein, a model molecule Hcit-res (Figure 12) was created. 


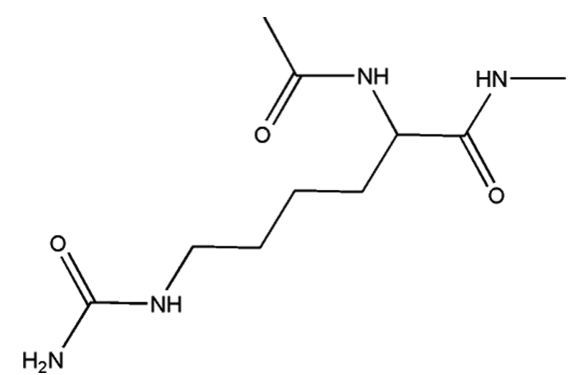

Figure 12. Model molecule Hcit-res to mimic homocitrulline residue.

The docking grids set up in Python Molecule Viewer (PMV), version 1.5.6, were centered in the pocket of $\mathrm{cH} 2-\mathrm{p} 1-\mathrm{C} 1$. The box for docking was set to $8 \AA \times 16 \AA \times 14 \AA$ to fully enclose the surface regions of all residues involved in $\mathrm{cH} 2-\mathrm{p} 1-\mathrm{C} 1$. AutoDock Vina was used for the docking experiment. ${ }^{46}$

\section{ASSOCIATED CONTENT}

\section{(s) Supporting Information}

The Supporting Information is available free of charge at https://pubs.acs.org/doi/10.1021/acsomega.0c05481.

SDS-PAGE bands of native HSA and cHSA; DLS size distribution of HSA, cHSA-1, and cHSA-2; sequence alignment results of four rounds of biopanning on cHSA-2; ITC raw titration data and fitting of integrated heat plots of peptide $\mathrm{cH} 2$-p1 titration into anti-Hcit; and frequency of amino acids included in the result of biopanning on cHSA-2 (PDF)

\section{AUTHOR INFORMATION}

\section{Corresponding Author}

Larry D. Unsworth - Department of Biomedical Engineering and Department of Chemical and Materials Engineering, University of Alberta, Edmonton, Alberta T6G 2V2, Canada; (1) orcid.org/0000-0003-3162-3545;

Email: lunswort@ualberta.ca

\section{Authors}

Yuhao Ma - Department of Biomedical Engineering, University of Alberta, Edmonton, Alberta T6G 2V2, Canada; (1) orcid.org/0000-0001-7517-5786

Meng Wu - Department of Chemical and Materials Engineering, University of Alberta, Edmonton, Alberta T6G 1H9, Canada

Shuhui Li - Department of Chemical and Materials Engineering, University of Alberta, Edmonton, Alberta T6G 1H9, Canada

Marcello Tonelli - Department of Medicine, University of Calgary, Calgary, Alberta T2N 1N4, Canada

Complete contact information is available at:

https://pubs.acs.org/10.1021/acsomega.0c05481

\section{Notes}

The authors declare no competing financial interest.

\section{ACKNOWLEDGMENTS}

This study was funded by ALBERTA INNOVATES STRATEGIC RESEARCH PROJECT grant. The authors thank the staff members in Molecular Biology Services Unit (MBSU) at University of Alberta for providing the phage sequencing services. They also thank Feng Wang for providing all of the technical supports in biofacilities at National Research Council (Canada) during our phage display and ELISA works.

\section{REFERENCES}

(1) Nowicki, C.; Santome, J. A. Modification of Lysine-69 Reactivity in Bovine Growth-Hormone by Carbamylation of Its N-Terminal Group. Int. J. Pept. Protein Res. 1981, 18, 52-60.

(2) Beswick, H. T.; Harding, J. J. High-Molecular-Weight Crystallin Aggregate Formation Resulting from Nonenzymatic Carbamylation of Lens Crystallins-Relevance to Cataract Formation. Exp. Eye Res. 1987, 45, 569-578.

(3) Fazili, K. M.; Mir, M. M.; Qasim, M. A. Changes in Protein Stability Upon Chemical Modification of Lysine Residues of Bovine Serum-Albumin by Different Reagents. Biochem. Mol. Biol. Int. 1993, $31,807-816$.

(4) Lee, T. C. K.; Gibson, Q. H. Allosteric Properties of Carbamylated Hemoglobins. J. Biol. Chem. 1981, 256, 4570-4577.

(5) Shaw, D. C.; Moore, S.; Stein, W. H. Inactivation of Chymotrypsin by Cyanate. J. Biol. Chem. 1964, 239, PC671-PC673.

(6) De Furia, F. G.; Miller, D. R.; Cerami, A.; Manning, J. M. The effects of cyanate in vitro on red blood cell metabolism and function in sickle cell anemia. J. Clin. Invest. 1972, 51, 566-574.

(7) Van Lente, F.; McHugh, A.; Pippenger, C. E. Carbamylation of apo-aspartate aminotransferase: a possible mechanism for enzyme inactivation in uremic patients. Clin. Chem. 1986, 32, 2107-2108.

(8) Veronese, F. M.; Piszkiewicz, D.; Smith, E. L. Inactivation of bovine glutamate dehydrogenase by carbamyl phosphate and cyanate. J. Biol. Chem. 1972, 247, 754-759.

(9) Oimomi, M.; Hatanaka, H.; Yoshimura, Y.; Yokono, K.; Baba, S.; Taketomi, Y. Carbamylation of insulin and its biological activity. Nephron 1987, 46, 63-66.

(10) Mohar, D. S.; Barseghian, A.; Haider, N.; Domanski, M.; Narula, J. Atherosclerosis in chronic kidney disease: lessons learned from glycation in diabetes. Med. Clin. North Am. 2012, 96, 57-65.

(11) Nicholson, D. H.; Harkness, D. R.; Benson, W. E.; Peterson, C. M. Cyanate-induced cataracts in patients with sickle-cell hemoglobinopathies. Arch. Ophthalmol. 1976, 94, 927-930.

(12) Steinbrecher, U. P.; Fisher, M.; Witztum, J. L.; Curtiss, L. K. Immunogenicity of homologous low density lipoprotein after methylation, ethylation, acetylation, or carbamylation: generation of antibodies specific for derivatized lysine. J. Lipid Res. 1984, 25, 11091116.

(13) Farias, G.; Gonzalez-Billault, C.; Maccioni, R. B. Immunological characterization of epitopes on tau of Alzheimer's type and chemically modified tau. Mol. Cell. Biochem. 1997, 168, 59-66.

(14) Gross, M. L.; Piecha, G.; Bierhaus, A.; Hanke, W.; Henle, T.; Schirmacher, P.; Ritz, E. Glycated and carbamylated albumin are more "nephrotoxic" than unmodified albumin in the amphibian kidney. Am. J. Physiol. 2011, 301, F476-F485.

(15) Drechsler, C.; Kalim, S.; Wenger, J. B.; Suntharalingam, P.; Hod, T.; Thadhani, R. I.; Karumanchi, S. A.; Wanner, C.; Berg, A. H. Protein carbamylation is associated with heart failure and mortality in diabetic patients with end-stage renal disease. Kidney Int. 2015, 87, 1201-1208.

(16) Niwa, T. Removal of Protein-Bound Uraemic Toxins by Haemodialysis. Blood Purif. 2013, 35, 20-25.

(17) Shi, J.; Knevel, R.; Suwannalai, P.; van der Linden, M. P.; Janssen, G. M. C.; van Veelen, P. A.; Levarht, N. E. W.; van der Helmvan Mil, A. H. M.; Cerami, A.; Huizinga, T. W. J.; Toes, R. E. M.; Trouw, L. A. , Autoantibodies recognizing carbamylated proteins are present in sera of patients with rheumatoid arthritis and predict joint damage. Proc. Natl. Acad. Sci. U.S.A. 2011, 108, 17372-17377.

(18) Kraus, L. M.; Miyamura, S.; Pecha, B. R.; Kraus, A. P. Carbamoylation of Hemoglobin in Uremic Patients Determined by Antibody Specific for Homocitrulline (Carbamoylated Epsilon-NLysine). Mol. Immunol. 1991, 28, 459-463. 
(19) Apostolov, E. O.; Shah, S. V.; Ok, E.; Basnakian, A. G. Quantification of carbamylated LDL in human sera by a new sandwich ELISA. Clin. Chem. 2005, 51, 719-728.

(20) Turunen, S.; Koivula, M. K.; Risteli, L.; Risteli, J. Anticitrulline Antibodies Can Be Caused by Homocitrulline-Containing Proteins in Rabbits. Arthritis Rheum. 2010, 62, 3345-3352.

(21) Nakabo, S.; Hashimoto, M.; Ito, S.; Furu, M.; Ito, H.; Fujii, T.; Yoshifuji, H.; Imura, Y.; Nakashima, R.; Murakami, K.; Kuramoto, N.; Tanaka, M.; Satoh, J.; Ishigami, A.; Morita, S.; Mimori, T.; Ohmura, $\mathrm{K}$. Carbamylated albumin is one of the target antigens of anticarbamylated protein antibodies. Rheumatology 2017, 56, 1217-1226.

(22) Turunen, S.; Koivula, M.-K.; Risteli, L.; Risteli, J. Anticitrulline antibodies can be caused by homocitrulline-containing proteins in rabbits. Arthritis Rheum. 2010, 62, 3345-3352.

(23) Dekkers, J. S.; Verheul, M. K.; Stoop, J. N.; Liu, B. S.; IoanFacsinay, A.; van Veelen, P. A.; de Ru, A. H.; Janssen, G. M. C.; Hegen, M.; Rapecki, S.; Huizinga, T. W. J.; Trouw, L. A.; Toes, R. E. M. Breach of autoreactive B cell tolerance by post-translationally modified proteins. Ann. Rheum. Dis. 2017, 76, 1449-1457.

(24) National Research Council (US) Committee on Methods of Producing Monoclonal Antibodies. Large-Scale Production of Monoclonal Antibodies. In Monoclonal Antibody Production; National Academies Press: Washington, DC, 1999; p 5.

(25) Pande, J.; Szewczyk, M. M.; Grover, A. K. Phage display: Concept, innovations, applications and future. Biotechnol. Adv. 2010, 28, 849-858.

(26) Fang, Y. M.; Lin, D. Q.; Yao, S. J. Review on biomimetic affinity chromatography with short peptide ligands and its application to protein purification. J. Chromatogr. A 2018, 1571, 1-15.

(27) Berg, A. H.; Drechsler, C.; Wenger, J.; Buccafusca, R.; Hod, T.; Kalim, S.; Ramma, W.; Parikh, S. M.; Steen, H.; Friedman, D. J.; Danziger, J.; Wanner, C.; Thadhani, R.; Karumanchi, S. A. Carbamylation of Serum Albumin as a Risk Factor for Mortality in Patients with Kidney Failure. Sci. Transl. Med. 2013, 5, No. 175ra29.

(28) Lefranc, M. P.; Giudicelli, V.; Duroux, P.; Jabado-Michaloud, J.; Folch, G.; Aouinti, S.; Carillon, E.; Duvergey, H.; Houles, A.; PaysanLafosse, T.; Hadi-Saljoqi, S.; Sasorith, S.; Lefranc, G.; Kossida, S. IMGT (R), the international ImMunoGeneTics information system (R) 25 years on. Nucleic Acids Res. 2015, 43, D413-D422.

(29) Giudicelli, V.; Duroux, P.; Ginestoux, C.; Folch, G.; JabadoMichaloud, J.; Chaume, D.; Lefranc, M. P. IMGT/LIGM-DB, the IMGT comprehensive database of immunoglobulin and $\mathrm{T}$ cell receptor nucleotide sequences. Nucleic Acids Res. 2006, 34, D781D784.

(30) Raats, J. M. H. Recombinant human monoclonal autoantibodies specific for citrulline-containing peptides from phage display libraries derived from patients with rheumatoid arthritis. J. Rheumatol. 2003, 30, 1696-1711.

(31) Verheul, M. K.; van Veelen, P. A.; van Delft, M. A. M.; de Ru, A.; Janssen, G. M. C.; Rispens, T.; Toes, R. E. M.; Trouw, L. A. Pitfalls in the detection of citrullination and carbamylation. Autoimmun. Rev. 2018, 17, 136-141.

(32) Sato, A. K.; Sexton, D. J.; Morganelli, L. A.; Cohen, E. H.; Wu, Q. L.; Conley, G. P.; Streltsova, Z.; Lee, S. W.; Devlin, M.; DeOliveira, D. B.; Enright, J.; Kent, R. B.; Wescott, C. R.; Ransohoff, T. C.; Ley, A. C.; Ladner, R. C. Development of mammalian serum albumin affinity purification media by peptide phage display. Biotechnol. Prog. 2002, 18, 182-192.

(33) Gaser, D.; Strukelj, B.; Bratkovic, T.; Kreft, S.; Pungercar, J.; Lunder, M. Cross-affinity of Peptide Ligands Selected from Phage Display Library Against Pancreatic Phospholipase A2 and Ammodytoxin C. Acta Chim. Slov. 2009, 56, 712-717.

(34) Zhao, W. X.; Yuan, H.; Xu, X.; Ma, L. Isolation and Initial Application of a Novel Peptide That Specifically Recognizes the Neural Stem Cells Derived from Rhesus Monkey Embryonic Stem Cells. J. Biomol. Screen. 2010, 15, 687-694.

(35) Segvich, S. J.; Smith, H. C.; Kohn, D. H. The adsorption of preferential binding peptides to apatite-based materials. Biomaterials 2009, 30, 1287-1298.
(36) Turnbull, W. B.; Daranas, A. H. On the value of c: Can low affinity systems be studied by isothermal titration calorimetry? J. Am. Chem. Soc. 2003, 125, 14859-14866.

(37) Hansen, L. D.; Fellingham, G. W.; Russell, D. J. Simultaneous determination of equilibrium constants and enthalpy changes by titration calorimetry: Methods, instruments, and uncertainties. Anal. Biochem. 2011, 409, 220-229.

(38) Jaisson, S.; Pietrement, C.; Gillery, P. Carbamylation-Derived Products: Bioactive Compounds and Potential Biomarkers in Chronic Renal Failure and Atherosclerosis. Clin. Chem. 2011, 57, 1499-1505.

(39) Gasteiger, E.; Hoogland, C.; Gattiker, A.; Duvaud, S.; Wilkins, M. R.; Appel, R. D.; Bairoch, A. Protein Identification and Analysis Tools on the ExPASy Server. In The Proteomics Protocols Handbook; Walker, J. M., Ed.; The Proteomics Protocols Handbook: 2005; Vol. 2005, pp 571-607.

(40) Aghaee, E.; Ghasemi, J. B.; Manouchehri, F.; Balalaie, S. Combined docking, molecular dynamics simulations and spectroscopic studies for the rational design of a dipeptide ligand for affinity chromatography separation of human serum albumin. J. Mol. Model. 2014, 20, No. 2389.

(41) Guilloton, M.; Karst, F. A Spectrophotometric Determination of Cyanate Using Reaction with 2-Aminobenzoic Acid. Anal. Biochem. 1985, 149, 291-295.

(42) Zhang, Y. I-TASSER server for protein 3D structure prediction. BMC Bioinf. 2008, 9.

(43) Roy, A.; Kucukural, A.; Zhang, Y. I-TASSER: a unified platform for automated protein structure and function prediction. Nat. Protoc. 2010, 5, 725-738.

(44) Yang, J. Y.; Roy, A.; Zhang, Y. Protein-ligand binding site recognition using complementary binding-specific substructure comparison and sequence profile alignment. Bioinformatics 2013, 29, 2588-2595.

(45) Yang, J.; Roy, A.; Zhang, Y. BioLiP: a semi-manually curated database for biologically relevant ligand-protein interactions. Nucleic Acids Res. 2013, 41, D1096-D1103.

(46) Trott, O.; Olson, A. J. Software News and Update AutoDock Vina: Improving the Speed and Accuracy of Docking with a New Scoring Function, Efficient Optimization, and Multithreading. J. Comput. Chem. 2010, 31, 455-461.

(47) Fan, G.; Dundas, C. M.; Zhang, C.; Lynd, N. A.; Keitz, B. K. Sequence-Dependent Peptide Surface Functionalization of MetalOrganic Frameworks. ACS Appl. Mater. Interfaces 2018, 10, 1860118609 .

(48) Schönberger, N.; Braun, R.; Matys, S.; Lederer, F. L.; Lehmann, F.; Flemming, K.; Pollmann, K. Chromatopanning for the identification of gallium binding peptides. J. Chromatogr. A 2019, $1600,158-166$. 